\title{
Naloxone inhibits nicotine-induced receptor current and catecholamine secretion in bovine chromaffin cells
}

\author{
Angelo R. Tomé ${ }^{\mathrm{a}, 1}$, Victor Izaguirre ${ }^{\mathrm{b}, 1}$, Luís M. Rosário ${ }^{\mathrm{a}}$, Valentín Ceña ${ }^{\mathrm{b}}$, \\ Carmen González-García ${ }^{\mathrm{b}, *}$
}

\begin{abstract}
${ }^{a}$ Department of Biochemistry, Faculty of Sciences and Technology and Center for Neuroscience and Cell Biology, University of Coimbra, Coimbra, Portugal

${ }^{\mathrm{b}}$ Centro Regional de Investigaciones Biomédicas and Departamento de Ciencias Médicas, Facultad de Medicina, Universidad de Castilla-La Mancha, Edif Benjamín Palencia, Avda. España, s/n, E-02071 Albacete, Spain
\end{abstract}

Accepted 6 March 2001

\begin{abstract}
Nicotine-induced catecholamine (CA) secretion and inward ionic currents were inhibited by the opioid antagonist naloxone in cultured bovine chromaffin cells. Naloxone inhibited nicotine-induced CA secretion, as detected by an on-line real-time electrochemical technique, in a dose-dependent manner $\left(\mathrm{IC}_{50}=29 \mu \mathrm{M}\right)$. In voltage-clamped chromaffin cells, nicotine $(10 \mu \mathrm{M})$ evoked an average peak inward current of $-146 \mathrm{pA}$ that was inhibited by low concentrations of naloxone $(42 \%$ at $0.1 \mu \mathrm{M})$. The antagonist also inhibited total charge influx associated with nicotinic receptor activation $(53 \%$ at $0.1 \mu \mathrm{M})$. This provides strong evidence that naloxone modulation of nicotine-induced CA secretion does not involve opioid receptors but results from the direct interaction with the nicotinic receptor itself, which might also be the case for other related opioid compounds. (c) 2001 Elsevier Science B.V. All rights reserved.
\end{abstract}

Theme: Neurotransmitters, modulators, transporters, and receptors

Topic: Opioid receptors

Keywords: Opioids; Nicotinic receptor; Currents; Catecholamine secretion; Patch-clamp

\section{Introduction}

Chromaffin cells secrete catecholamines (CA) in response to different stimuli [17,21]. Under physiological conditions, acetylcholine is released from splanchnic nerve terminals and interacts with nicotinic receptors producing depolarization of chromaffin cell membrane $[18,23]$. This depolarization opens voltage-dependent $\mathrm{Ca}^{2+}$ channels [7,11], which produces an increase in intracellular $\mathrm{Ca}^{2+}$ levels $\left(\left[\mathrm{Ca}^{2+}\right]_{\mathrm{i}}\right)[2,7]$ and CA and ATP secretion $[3,9]$.

Bovine chromaffin cells co-release opioid peptides together with CA following nicotinic receptor stimulation [19] and their membranes possess $\mu, \delta$ and $\kappa$ opioid receptors [16]. The secreted opioid peptides might inhibit nicotine-induced CA secretion from chromaffin cells [15],

\footnotetext{
*Corresponding author. Tel.: +34-967-599-200.

E-mail address: cgonzale@med-ab.uclm.es (C. González-García).

${ }^{1}$ Both authors contributed equally to this paper.
}

but this effect does not seem to be mediated by opioid receptors since opioid antagonists, like naloxone, have the same effect [8]. Moreover, it has been shown that activation of opioid $\kappa$ receptors inhibits nicotine-induced $\mathrm{Ca}^{2+}$ entry into chromaffin cells but this effect is not prevented by opioid antagonists like Mr2266 [1].

Cholinergic nicotinic receptors are targets for an increasing number of drugs and toxins like dihydropyridines [20], $\omega$-agatoxin IVA, a specific blocker of P/Q type voltagedependent $\mathrm{Ca}^{2+}$ channels [13], the diuretic cyclothiazide [22] and tricyclic antidepressants [14]. Interaction of these substances with the receptor might interfere with its function.

To elucidate the mechanism of action of the inhibition of nicotine-induced CA secretion by opioid antagonists, we have studied the effect of naloxone, a well known opioid antagonist, on nicotine-induced CA secretion from chromaffin cells in a continuously superfused cellular system and explored the effect of naloxone on nicotine- 
induced inward currents. We have found that the antagonist is able to inhibit, in a dose-dependent and reversible manner, nicotine-induced CA secretion and inward currents.

\section{Materials and methods}

\subsection{Cell isolation and culture}

Bovine chromaffin cells were isolated using collagenase digestion and purified through a Percoll gradient as previously described [4]. For electrophysiological recordings $10^{6}$ cells were plated in a $35-\mathrm{mm}$ diameter Petri dish (Bibby Science Products, Stone, UK). Cultured cells were kept at $37^{\circ} \mathrm{C}$ under an atmosphere of $5 \% \mathrm{CO}_{2}$ for up to 5 days.

\subsection{Catecholamine secretion}

Catecholamine secretion experiments were performed as previously described [20] with minor modifications. Briefl$y$, after 2-4 days of culture, chromaffin cells (ca. $2 \times 10^{6}$ cells) were transferred to a perfusion chamber (a 2.3-mm diameter, $0.8-\mu \mathrm{m}$ membrane pore, disposable filter unit) and continuously perfused at $2 \mathrm{ml} / \mathrm{min}$ with Krebs-Hepes (K-H) solution with the following composition (in mmol/ 1): $\mathrm{NaCl}, 140 ; \mathrm{KCl}, 5 ; \mathrm{CaCl}_{2}, 2 ; \mathrm{MgCl}_{2}, 1$, Hepes, 10; and glucose, 5; $\mathrm{pH}$ was adjusted to a value between 7.3 and 7.4. The cell bed was stimulated with nicotine $(10 \mu \mathrm{M})$ every $10 \mathrm{~min}$, beginning after $15 \mathrm{~min}$ from the start of perfusion. The effluent solution exiting the perfusion chamber was driven into an electrochemical detector (Omni 90 potentiostat, Cypress Systems, Lawrence, KS, USA) for direct continuous on-line measurement of catecholamine oxidation current (anodic potential set at +650 $\mathrm{mV})$. When used, naloxone-containing solutions were perfused 2 min prior to and during nicotine application. The inhibitory effect of naloxone was calculated by comparing the area under the curve for the electrochemical signal observed in the presence of the drug with the mean area of the nicotine-induced signals observed before and after it. All the experiments were performed at room temperature $\left(22-24^{\circ} \mathrm{C}\right)$.

\subsection{Electrophysiological recording}

Recording of chromaffin cell nicotinic receptor-activated currents under voltage-clamp was performed, using the nystatin-perforated patch-clamp technique, as previously described [13]. Chromaffin cells were bathed in a solution with the following ionic composition (in mmol/l): $\mathrm{NaCl}$ 140; $\mathrm{KCl}$ 5.9; $\mathrm{MgSO}_{4} 1.2 ; \mathrm{CaCl}_{2} 2.5 ;$ Hepes 15 and glucose $11(\mathrm{pH} \mathrm{7.4)}$. The intracellular solution had the following composition (in mmol/l): $\mathrm{KCl} 55 ; \mathrm{K}_{2} \mathrm{SO}_{4} 50$; $\mathrm{MgSO}_{4}$ 7; Hepes 10 and nystatin $250 \mu \mathrm{g} / \mathrm{ml}(\mathrm{pH} 7.2)$.
After $10 \mathrm{~min}$, nicotine $(10 \mu \mathrm{M})$ was applied for $4 \mathrm{~s}$ using a fast perfusion system under computer control (DAD-12 superfusion system; Adams and List, NY). This nicotine pulse was repeated three times $\left(S_{1}, S_{2}, S_{3}\right)$ at 15-min intervals. When used, naloxone was perfused $1 \mathrm{~s}$ before and during $S_{2}$.

\subsection{Reagents}

Nicotine and naloxone were obtained from Sigma ( $\mathrm{St}$ Louis, MO) penicillin and streptomycin from Bio-Whittaker Bioproducts (Walkersville, MD) and bovine serum albumin from Calbiochem (La Jolla, CA). All other reagents were obtained from different commercial sources and were of the maximal available purity.

\section{Results}

\subsection{Catecholamine secretion}

Introduction of nicotine $(10 \mu \mathrm{M})$ in the perfusion flow resulted in the detection of a transitory CA secretion indicating that the agonist induced $\mathrm{CA}$ release from the chromaffin cells present in the perfusion chamber [5]. The electrochemical signal was equivalent to the release of $1.0 \pm 0.3 \mathrm{nmol} \mathrm{CA} / 10^{6}$ cells (mean \pm S.E.M., $n=3$ ). The amplitude of the electrochemical signal tended to decrease as the stimulation of $\mathrm{CA}$ secretion with nicotine was repeated every $10 \mathrm{~min}$ (Fig. 1A). Naloxone produced a marked decrease in the nicotine-induced secretory episodes. The inhibitory effect of naloxone on the nicotineinduced CA release was dose-dependent. The blockade was almost complete at the highest drug concentration used, $200 \mu \mathrm{M}$ (96 $\pm 2 \%$ inhibition, $n=5$; Fig. 1, panel A). The $\mathrm{IC}_{50}$ for the blocking effect of naloxone, as determined from the dose-response curve, was $29 \mu \mathrm{M}$ (Fig. 1B).

\subsection{Nicotine-induced inward currents}

Nicotine $(10 \mu \mathrm{M})$ perfusion for $4 \mathrm{~s}$ evoked an inward current that amounted to $-146 \pm 27 \mathrm{pA}(n=19)$, producing a total net charge flux of $495 \pm 56 \mathrm{pC}(n=19)$. When the exposure to nicotine was repeated $15 \mathrm{~min}$ later, the ratio $S_{2} / S_{1}$ for peak current was $0.94 \pm 0.07 \quad(n=5)$ and for charge influx was $1.02 \pm 0.09(n=5)$. The presence of naloxone during $S_{2}$ produced a marked decrease in both peak current and charge influx that was reversible upon removal of the drug (Fig. 2). The inhibitory effect of naloxone was dose-dependent. The blockade reached around $65 \%$ for peak current and $68 \%$ for total charge influx at $10 \mu \mathrm{M}$ drug concentration (Table 1). 


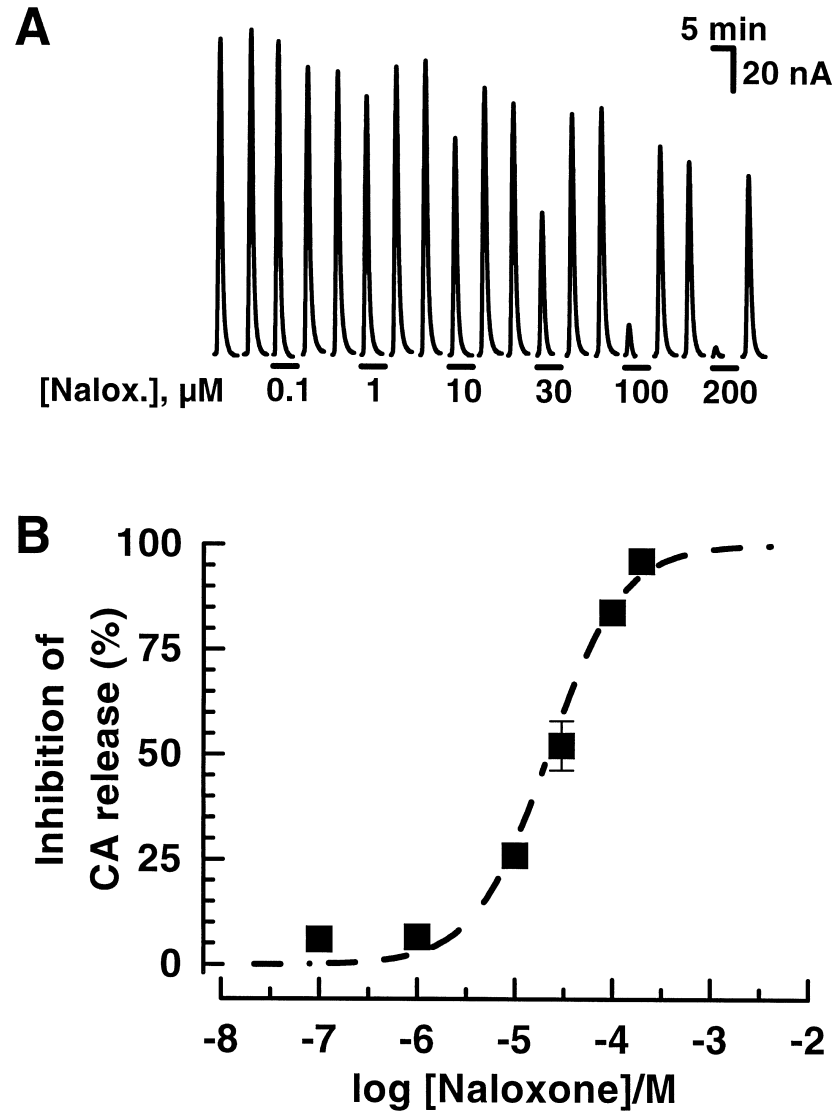

Fig. 1. Effect of naloxone on nicotine-induced catecholamine secretion. (A) Secretory episodes evoked by consecutive applications of nicotine (10 $\mu \mathrm{M}, 10 \mathrm{~min}$ apart) to the perfused chromaffin cell population. The horizontal bars indicate nicotine-induced secretory episodes recorded in the presence of naloxone (naloxone concentrations, in $\mu \mathrm{M}$, are indicated below the bars). (B) Dose-response curve for the inhibitory effect of naloxone on the nicotine-induced CA secretion. Data were calculated as stated in Material and methods and represent mean \pm S.E.M. of three different experiments.

\section{Discussion}

The results presented here show that the non-selective opioid antagonist naloxone potently blocks nicotine-induced CA secretion from chromaffin cells and this effect might be explained by the reversible blockade of nicotineinduced inward currents in chromaffin cells.

Chromaffin cells in culture might secrete and accumulate in its vicinity different products, including endogenous opioids [19], that might produce a negative feedback on secretion. Support for this view comes from studies that indicate that cell superfusion resulting in fast removal of locally secreted products produces an increase in $\mathrm{Ca}^{2+}$ current amplitude [10]. Our data indicate that this mechanism is not involved in naloxone effects because, in order to prevent tonic modifications of nicotinic receptor-mediated functions, both the CA secretion studies and electrophysiological recordings have been performed under continuous fast superfusion of chromaffin cells that, in all

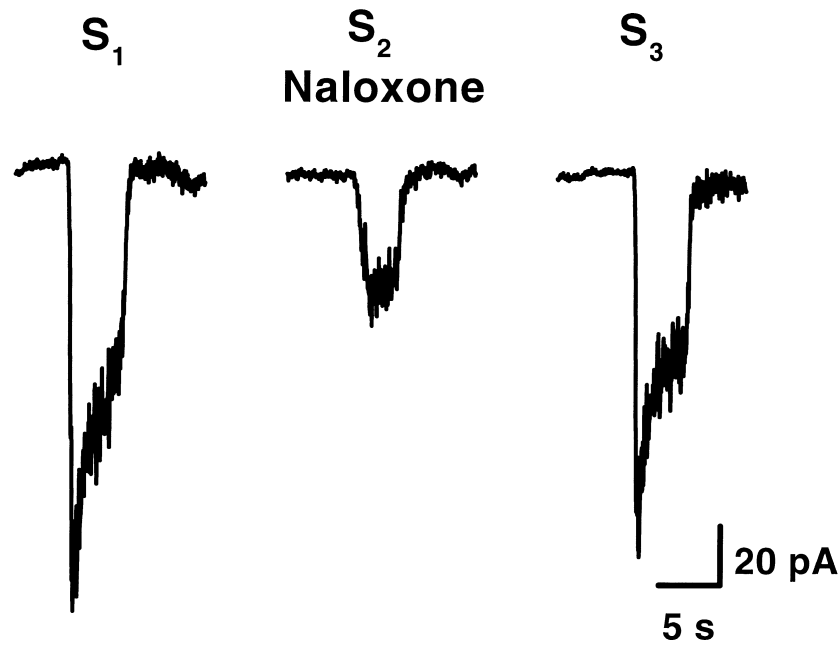

Fig. 2. Nicotine-induced inward currents in chromaffin cells. Inward currents evoked by three successive exposures $\left(S_{1}, S_{2}, S_{3} ; 4 \mathrm{~s} ; 15 \mathrm{~min}\right.$ apart) to nicotine $(10 \mu \mathrm{M})$ from a holding potential of $-55 \mathrm{mV}$. Naloxone $(10 \mu \mathrm{M})$ was present $1 \mathrm{~s}$ before and during $S_{2}$. The experiment was repeated six more times with similar results.

likelihood, has removed the locally secreted products. The inhibitory mechanism of opioids on nicotine-evoked CA secretion has been controversial since the lack of stereospecificity [8] and non reversion by opioid antagonists $[1,8]$ were shown suggesting that specific opioid receptors were not involved in this action. Our electrophysiological data support this proposal and indicate that the nicotinic receptor might be a target through which opioid drugs might regulate directly nicotinic receptor-mediated functions. Noteworthy is the fact that the cholinergic nicotinic receptors from chromaffin cells have been shown to interact with a broad range of unrelated compounds $[6,12,13,22]$ indicating that such a process might be a pharmacologically relevant mechanism to regulate chromaffin cell secretory activity.

In summary, the data presented here suggest that the non-selective opioid antagonist naloxone blocks nicotineinduced CA secretion by a direct interaction with nicotinic receptors, located on the plasmalemma of chromaffin cells,

Table 1

Effect of naloxone on nicotine-induced inward currents and net charge influx in bovine chromaffin cells

\begin{tabular}{llll}
\hline $\begin{array}{l}\text { Drug added together with } \\
\text { nicotine during } S_{2}\end{array}$ & $n$ & $\begin{array}{l}\text { Peak current } \\
\left(S_{2} / S_{1} \text { ratio }\right)\end{array}$ & $\begin{array}{l}\text { Total net charge } \\
\text { influx }\left(S_{2} / S_{1} \text { ratio }\right)\end{array}$ \\
\hline None & 5 & $0.94 \pm 0.07$ & $1.02 \pm 0.09$ \\
Naloxone $0.1 \mu \mathrm{M}$ & 7 & $0.54 \pm 0.05^{*}$ & $0.47 \pm 0.06^{*}$ \\
Naloxone $10 \mu \mathrm{M}$ & 7 & $0.33 \pm 0.03^{* *}$ & $0.33 \pm 0.03^{* *}$ \\
\hline
\end{tabular}

Bovine chromaffin cells were exposed for $4 \mathrm{~s}$ to nicotine $(10 \mu \mathrm{M})$ as stated in Material and methods. Nicotine stimulation was repeated three times $\left(S_{1}, S_{2}, S_{3}\right)$ at 15 -min intervals. Naloxone was perfused to the cell 1 $\mathrm{s}$ before and during $S_{2}$. The average values for inward peak current and total net charge influx during $S_{1}$ were $-146 \pm 27 \mathrm{pA}(n=19)$ and $495 \pm 56$ pC $(n=19)$. Data represent mean \pm S.E.M. $* P<0.001$; ** $P<0.0001$ compared to control. 
and that opioid-mediated inhibition of nicotine-evoked CA secretion is not mediated by specific opioid receptors.

\section{Acknowledgements}

This work has been supported in part by grants SAF960169 and 1FD97-0500 from CICYT to V.C.; PRAXIS 2/2.1/SAU/1179/95 from Fundação para a Ciência e Tecnologia (FCT) to L.M.R. and SAF98-0140 from CICYT to C.G.G.

\section{References}

[1] S.J. Bunn, P.R. Dunkley, Opioid inhibition of nicotine-induced 45Ca2(+)-uptake into cultured bovine adrenal medullary cells, Biochem. Pharmacol. 41 (1991) 715-722.

[2] R.D. Burgoyne, The relationship between secretion and intracellular free calcium in bovine adrenal chromaffin cells, Biosci. Rep. 4 (1984) 605-611.

[3] J.C. Brooks, S. Treml, Catecholamine secretion by chemically skinned cultured chromaffin cells, J. Neurochem. 40 (1983) 468473.

[4] S. Calvo, R. Granja, G.C. Gonzalez, V. Ceña, Catecholamine secretion, calcium levels and calcium influx in response to membrane depolarization in bovine chromaffin cells, Neuroscience 68 (1995) 265-272.

[5] E. Castro, J. Mateo, A.R. Tome, R.M. Barbosa, P.M. Miras, L.M. Rosario, Cell-specific purinergic receptors coupled to $\mathrm{Ca}^{2+}$ entry and $\mathrm{Ca}^{2+}$ release from internal stores in adrenal chromaffin cells. Differential sensitivity to UTP and suramin, J. Biol. Chem. 270 (1995) 5098-5106.

[6] V. Ceña, G.P. Nicolás, P. Sánchez-García, S.M. Kirpekar, A.G. García, Pharmacological dissection of receptor-associated and voltage-sensitive ionic channels involved in catecholamine release, Neuroscience 4 (1983) 1455-1462.

[7] V. Ceña, A. Stutzin, E. Rojas, Effects of calcium and Bay K-8644 on calcium currents in adrenal medullary chromaffin cells, J. Membr. Biol. 112 (1989) 255-265.

[8] D.M. Dean, S. Lemaire, B.G. Livett, Evidence that inhibition of nicotine-mediated catecholamine secretion from adrenal chromaffin cells by enkephalin, beta-endorphin, dynorphin (1-13), and opiates is not mediated via specific opiate receptors, J. Neurochem. 38 (1982) 606-614.

[9] W.W. Douglas, A.M. Poisner, On the relation between ATP splitting and secretion in the adrenal chromaffin cell: extrusion of ATP (unhydrolysed) during release of catecholamines, J. Physiol. 183 (1966) 249-256.

[10] A. Elhamdani, J.L. Bossu, A. Feltz, Evolution of the $\mathrm{Ca}^{2+}$ current during dialysis of isolated bovine chromaffin cells: effect of internal calcium, Cell Calcium 16 (1994) 357-366.

[11] E.M. Fenwick, A. Marty, E. Neher, Sodium and calcium channels in bovine chromaffin cells, J. Physiol. 331 (1982) 599-635.

[12] J.M. Fernández-Fernández, R. Granja, V. Izaguirre, C. GonzálezGarcía, V. Ceña, Omega-conotoxin GVIA blocks nicotine-induced catecholamine secretion by blocking the nicotinic receptor-activated inward currents in bovine chromaffin cells, Neurosci. Lett. 191 (1995) 59-62.

[13] R. Granja, J.M. Fernández-Fernández, V. Izaguirre, C. GonzálezGarcía, V. Ceña, Omega-agatoxin IVA blocks nicotinic receptor channels in bovine chromaffin cells, FEBS Lett. 362 (1995) 15-18.

[14] V. Izaguirre, J. Fernandez-Fernández, V. Ceña, C. Gonzalez-García, Tricyclic antidepressants block cholinergic nicotinic receptors and ATP secretion in bovine chromaffin cells, FEBS Lett. 418 (1997) $39-42$.

[15] K. Kumakura, F. Karoum, A. Guidotti, E. Costa, Modulation of nicotinic receptors by opiate receptor antagonists in cultured adrenal chromaffin cells, Nature 283 (1980) 489-492.

[16] S. Lemaire, R. Day, M. Dumont, L. Chouinard, R. Calvert, Dynorphin and enkephalins in adrenal paraneurons. Opiates in adrenal medulla, Can. J. Physiol. Pharmacol. 62 (1984) 484-492.

[17] G.P. Lewis, Physiological mechanisms controlling secretory activity of adrenal medulla, in: Handbook of Physiology - Endocrinology (IV), 1994, pp. 309-319.

[18] B.G. Livett, P. Boksa, Receptors and receptor modulation in cultured chromaffin cells, Can. J. Physiol. Pharmacol. 62 (1984) 467-476.

[19] B.G. Livett, D.M. Dean, L.G. Whelan, S. Udenfriend, J. Rossier, Co-release of enkephalin and catecholamines from cultured adrenal chromaffin cells, Nature 289 (1981) 317-319.

[20] M.G. López, R.I. Fonteriz, L. Gandia, M. de la Fuente, M. Villarroya, J. Garcia-Sancho, A.G. Garcia, The nicotinic acetylcholine receptor of the bovine chromaffin cell, a new target for dihydropyridines, Eur. J. Pharmacol. 247 (1993) 199-207.

[21] E. Neher, L. Von Rüden, Depression and augmentation of quantal release in adrenal chromaffin cells, Adv. Second Messenger Phosphoprotein Res. 29 (1994) 353-362.

[22] J.M. Nooney, A. Feltz, Inhibition by cyclothiazide of neuronal nicotinic responses in bovine chromaffin cells, Br. J. Pharmacol. 114 (1995) 648-655.

[23] A.S. Schneider, H.T. Cline, K. Rosenheck, M. Sonenberg, Stimulussecretion coupling in isolated adrenal chromaffin cells: calcium channel activation and possible role of cytoskeletal elements, J. Neurochem. 37 (3) (1981) 567-575. 